\title{
Evaluation of Management Earnings Forecast Error and Information Content of Accruals: Listed Companies in Tehran Stock Exchange
}

\author{
${ }^{*}$ Mehdi Moradzadehfard ${ }^{1}$, Hemad Nazari² \\ ${ }^{1}$ Islamic Azad University, Karaj, Iran \\ ${ }^{2}$ Islamic Azad University, Tehran, Iran \\ *moradzadehfard@kiau.ac.ir
}

\begin{abstract}
Aim of this study is studying relation of management earnings forecast error and information content of accruals. Thus, the sample consists of 71 companies were selected for the period 2003-2011. In this study discretionary accruals is used as independent variables. The results suggest that there is a significant negative relationship between earnings management forecast error and the total discretionary accruals. These results indicate that other assumptions that management forecasts for financing through equity or debt generates a significant positive relationship between positive accruals and management earnings forecast error. In addition, through equity or debt financing outlook, there is no significant relationship between earnings forecast error and negative accruals.
\end{abstract}

Keywords: Management forecasts, earnings forecast error, discretionary accruals

\section{Introduction}

The main objective of financial reporting is to provide information for decision-making users of financial information. One of the features that are necessary for the relevant financial information is usefulness in forecasting. Expected to help investors improve their decision-making process and reduce the risk of their decisions. In addition to the contained information in financial statements, as well as extensive information disclosed outside the financial statements based on predictions and estimates are subject to management. The information disclosed outside the financial statements reflects the management anticipated profit forecasts about future prospects. It is expected that due to imperfect estimates of future business managers, financial statements and disclosed information throughout the common errors they contain. Studies (Brockman and Cicone, 2008, Hirst et al 2008) indicate that management forecasts will affect stock prices, stock market liquidity, and analysts predict. Financial analysts, managers and investors have been paying particular attention to earnings reports. Interest rate is published predictions between users and any review will look at it closely. In the meantime, some efforts to escape from the attention devoted to the net profit figure, users views are focused the constituent items of interest. Hence, in addition to net income, one of the most important features, namely the interest accruals should also be considered. Hence, net income adjusted to reflect accruals quality is important. Research results (Jog \& Macconomy, 2003) has shown that investors rely on information such as earnings per share forecast and its shares are priced. Investors decide to buy, sell or hold shares of profits based on projected added importance earnings forecast error. The profit forecast error has an important role in the secondary market. Therefore, in this study we are to examine relation of management earnings forecasts information content accruals.

\section{Theoretical Study}

Accruals and earnings forecast error: One of the functions that are defined for accounting, provide useful information to help investors determine the value of securities and help to get informed investment decisions. Benefits anticipated by management in many countries are among the disclosed voluntarily information. In Iran, annual earnings forecast is applied 30 days before new financial year and auditors opinion is took 20 days after it.

Anticipated profits can be useful in the following cases:

- To help assess the profitability of the business unit

- Determine the current value or the total value of company shares 
- In estimation of investment risk in commercial units (Jog \& Macconomy, 2003).

- The estimated risk of lending to business units (Hendrikson \& Van berda, 1992).

Business units do not want to forecast some of forecasts because of some reasons: 1- forecasts lost their values harshly, 2- forecasts may be in disadvantage of unit and be advantaged of its opponents, 3management may cause itself to get its forecasts, and for this reason may make short term decisions that does not take in line with the general interest of shareholders. 4 - Failure of units in the realization of profit forecasts could cause shareholder dissatisfaction.

\section{Graphs 1: Affecting factors of earnings forecast error}

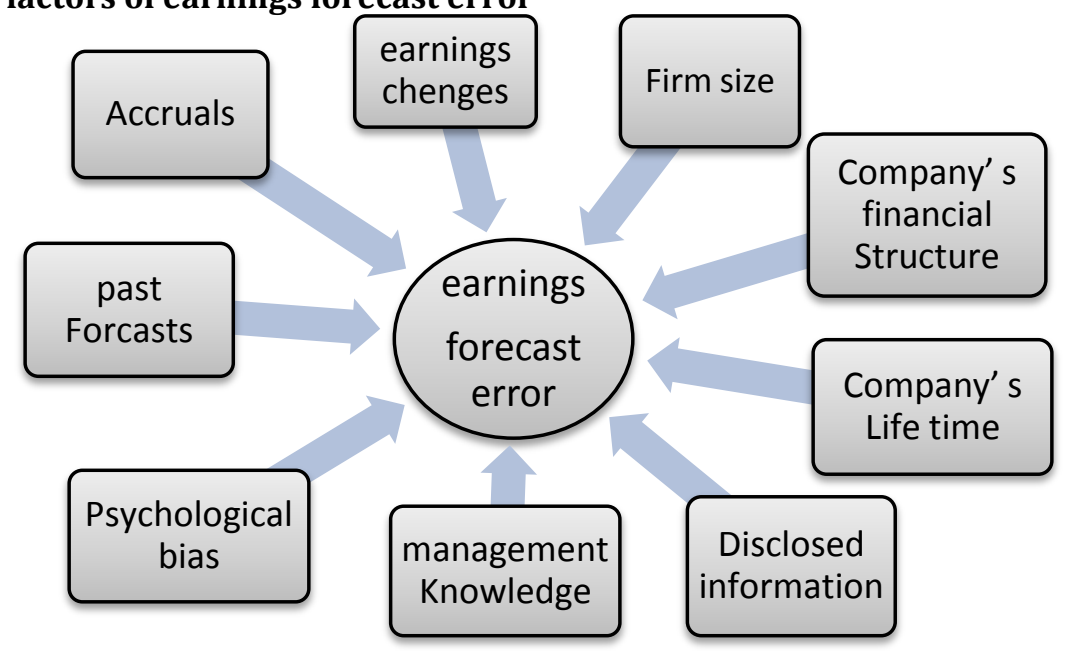

Accruals as one of the elements affecting earnings forecast error, s considered as the independent variable i in this study. In addition, other factors that their measurements are possible are considered as control variables. In accounting information, accounting profit is considered as the main source of information about the profitability and future cash flows. Accounting profit is measured Based on accruals and hence, there is the smell between earnings and cash flows are reported as operating cash flow:

Accounting profit $=$ cash component + accrual Component

Accounting profits $=$ cash flows + accruals

The main aim of financial accounting is to supply information that is useful for users and accrual accounting is for achieving this aim. The objection is based on commitment, not objective facts and figures - the figure of profit - is compared with the cash basis. In fact, due to factors such as judgment, allocation and estimated accrual is considered an integral part of not being objective. Understanding the properties of accruals is almost one of the most important objectives of financial accounting research. Optional components and nondiscretionary accruals can be (essentially) breakdown as follows:

1 - optional components of accruals, the following action on their commitment to apply controls that can manage such an inventory, accounts receivable and payable, bad receivables costs, depreciation costs and etc. 2 - Non-discretionary elements (inherent) of accruals: a commitment that the following action cannot manage to impose controls on their end benefits such as staff cost and etc.

Some facts that can be named for decreasing management forecast are error legal proceedings on behalf of shareholders, to prevent degradation and maintain credibility of company managers (job security).

\section{Literature Review}

Gong et al. (2009) have examined relationship between earnings forecast errors and accruals from another angle. They predict the relationship between accruals and earnings management in the coming year. Experimental results showed the positive relationship between earnings prediction error and accruals. Fang (2009) studied the role of management forecast accuracy in the estimation of management earnings forecast 
error. His own research concluded that significant and negative relationship between forecast accuracy and management forecast error. This finding is consistent with this hypothesis, we are optimistic that with lower levels of be predicted accuracy. The provisions are stronger with regard to the long time horizon. Wei Hong $\mathrm{Xu}$ (2009) investigated how management earnings forecasts fully reflect the benefits of accruals implies next year. Hutton and Stocken (2009) concluded in their study that previous predictions reputation allows companies to predict the behavior. Payne (2008) studied impact on the auditors' review as a decisive of management's earnings forecast error. He concluded in this study, auditors with high accuracy, cut the administrator in anticipated dividend. The information component of the bid-ask spread for less liquid stocks, the dispersion of analysts' earnings forecasts and the stock market reaction to earnings announcements and management earnings forecasts, all decreased in the post-reform period (Frijns et al., 2008; Dunstan et al., 2009; Huang et al., 2009).In addition, Huang et al. (2009) and Dunstan et al. (2011) found that firms increased the number of price-sensitive disclosures and earnings forecasts, which are more precise and accurate, to the capital market in the post-reform period. It is shown in Dunstan et al. (2011) that management earnings forecasts released through non-routine announcements tended to be more precise. Pae and Thornton (2010) show that analysts' earnings forecasts do not fully incorporate the implications of earnings conservatism. Yet it is still an open question whether managers fully adjust the effect of accounting conservatism on future earnings when they issue earnings forecasts.

\section{The Research hypotheses}

Hypothesis 1) there is negative correlation between accruals and future management earnings forecast error. Hypothesis 2) predicted for the management of funds through financial facilities, causes a significant positive relationship between positive accruals and management forecast error.

Hypothesis 3) to manage the anticipated funding from the financing facility creates a significant negative relationship between accruals and negative management earnings forecast error.

Hypothesis 4) management forecasts for financing through equity, creates a significant positive relationship between positive accruals and management forecast error profits.

Hypothesis 5) prediction for the management of financing through equity creates a significant negative correlation between accruals and negative management earnings forecast error.

\section{Methodology}

The objective of this research is applied research and in terms of nature is descriptive - correlation that has been done using multiple regression. In addition, proof of the theoretical component and research component of the argument is inductive. Data has been collected of computer databases (Rah-Avard Novin and Tadbir Pardaz softwares) and websites (irbours, irportfolio).

Population and sample selection: Statistical society of this study is all listed companies in Tehran Stock Exchange during 2003-2011. With regard to information and availability of their time doing research study, 5-year period from 2006 to 2011, has been set. Years 2003 to 2006 just to control uncertainty of the company's operating environment. Number of sample cases is 71 companies in 19 industries have been using the targeted (knockout) and according to the following criteria:

- Company Financial Year is 29 Stand (the last month in Iran calendar) the end of the fiscal year have not changed over the period considered.

- Companies cannot change. (Change in the nature of the activity is not occurring.)

- Companies trading should not be completely stopped during the study period.

- Not to be as capital investment companies, financial intermediation, holding, not Bank.

- The company must be profitable over the period of study.

Data analysis and testing hypotheses: After initial processing and the calculating variables by the software Excel, its result by using SPSS statistical analysis has been analyzed. 


\section{Research models to test hypotheses}

Model Hypothesis 1:

MFE $_{t}=\beta 0+\beta 1 D_{t-1}+\beta 2$ FIN $_{t}+\beta 3 R_{0 A}+1+\beta 4 Z_{t-1}+\beta 5$ Horizon $_{t}+\beta 6$ Retun $_{t}+\beta 7$ MFE $_{t-1}+\beta 8$ M/B $-1+\beta 9$ LNSize $_{t-1}+$ $\beta$ 10CFO-VOL $t-1+\beta$ 11SALE-GR-VOL $t-1+\beta 12$ OPCYCLE ${ }_{\mathrm{t}-1}+\varepsilon_{\mathrm{t}}$

Model of Hypothesis 2, 3, 4 and 5:

$\mathrm{MFE}_{\mathrm{t}}=\gamma 0+\gamma 1 \mathrm{DA}_{\mathrm{t}-1}+\gamma 2 \mathrm{DA}_{\mathrm{t}-1} \times \mathrm{POS}_{\mathrm{t}-1} \times \mathrm{FIN}_{\mathrm{t}}+\gamma 3 \mathrm{DA}_{\mathrm{t}-1} \times \mathrm{Neg}_{\mathrm{t}-1} \times \mathrm{FIN}_{\mathrm{t}}+\gamma 4 \mathrm{DA}_{\mathrm{t}-1} \times \mathrm{POS}_{\mathrm{t}-1}+\gamma 5 \mathrm{DA}_{\mathrm{t}-1} \times \mathrm{Neg}_{\mathrm{t}-}+\gamma 6 \mathrm{FIN}_{\mathrm{t}}+\gamma$ 7 HORIZON $_{\mathrm{t}}+\gamma 8$ RETURN $_{\mathrm{t}}+\gamma 9 \mathrm{M} / \mathrm{B}_{\mathrm{t}-1}+\gamma 10$ LNSIZE $_{\mathrm{t}-1}+$

$\beta_{12}, \ldots g \beta_{2} g \beta_{1}$ :Sensitivity coefficients of the studied variables

$e_{t}$ : The regression error

The only difference between models 2 and 3 with 4 and 5 is the type of financing. Making assumptions 2 and 3 in the debt financing (DFIN) and assumptions 4 and 5 in the form of stock financing (SFIN).

Operational definition of concepts and variables

Dependent variable: Management earnings forecast error: in management profit forecasts error in this study have been as the dependent variable and the predicted difference in annual earnings per share minus the actual earnings per share divided by financial period earnings forecasts.

$M F E=\sum\left|\frac{a_{t}-f_{t}}{f_{t}}\right| *(\% 100)$

at= Actual earnings at company

$\mathrm{ft}=$ expected company's profit

The independent variable: DAt-1 (discretionary accruals)

Expressed theoretical study of the contents in discretionary accruals as independent variables in this study is considered. Based on a comprehensive review Mac Nichols (1989), about 45 percent of the discretionary accruals, $18.2 \%$ of certain accruals and 7.3 percent of total accruals, used as an indicator of earnings management. In this study, discretionary accruals have been considered. In this study, the modified Jones model has been used Iranianized. On the basis of this model with the modified Jones model, the new model is with test stimuli affecting earnings management, consistent with the economic environment, social and cultural rights be offering in Iran:

In order to calculate discretionary accruals means items that managers have freedom about them, you must calculate first total accruals and non-discretionary accruals, and then discretionary accruals is the result of the difference between them,:

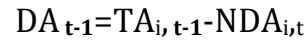

DAi, t: discretionary accruals in year $t$

TAi, t: total accruals

NDA: non-discretionary accruals

1 - To calculate total accruals using the following formula:

$\mathrm{TA}_{\mathrm{i}, \mathrm{t}}=\left(\Delta \mathrm{CA}_{\mathrm{i}, \mathrm{t}}-\Delta \mathrm{CL}_{\mathrm{i}, \mathrm{t}}-\Delta \operatorname{Cash}_{\mathrm{i}, \mathrm{t}}+\mathrm{STD}_{\mathrm{t}}-\mathrm{Dep}_{\mathrm{i}, \mathrm{t}}\right) /\left(\mathrm{MV}_{\mathrm{i}, \mathrm{t}}\right)$

In this regard:

$\mathrm{TAi}, \mathrm{t}$ : total accruals in year $\mathrm{t}$

$\Delta \mathrm{CAi}$, t: Change in current assets

$\Delta \mathrm{CLi}$, t: Change in current liabilities

$\Delta$ Cashi, t: Change in cash and cash equivalents

STDi, t: Changes in the interest of long-term debt

Depi, $t$ : The cost of depreciation of fixed assets and intangible

$\mathrm{MVi}$, t: The Company's market value

2 - For calculated non-discretionary accruals using the following formula:

$\mathrm{NDA}_{\mathrm{i}, \mathrm{t}}=\mathrm{a}_{1}\left(1 / \mathrm{MV}_{\mathrm{i}, \mathrm{t}}\right)+\mathrm{a}_{2}\left(\Delta \mathrm{REV}_{\mathrm{i}, \mathrm{t}}-\Delta \mathrm{REC}_{\mathrm{i}, \mathrm{t}}\right) / \mathrm{MV}_{\mathrm{i}, \mathrm{t}}+\mathrm{a}_{3}\left(\mathrm{PPE}_{\mathrm{i}, \mathrm{t}} / \mathrm{MV}_{\mathrm{i}, \mathrm{t}}\right)+\alpha_{4}\left(\mathrm{~A}_{\mathrm{i}, \mathrm{t}} / \mathrm{MV}_{\mathrm{i}, \mathrm{t}}\right)+\alpha_{5}\left(\mathrm{~T}_{\mathrm{i}, \mathrm{t}} / \mathrm{MV}_{\mathrm{i}, \mathrm{t}}\right)+\varepsilon_{\mathrm{t}}$

In this regard: 
NDAi, t: Non-discretionary accruals in year $t$

MVi, t: The Company's market value

$\triangle$ REVit: Change in net income

$\triangle \mathrm{RECi}$, $\mathrm{t}$ : Changes in net trade receivables

PPEi, t: The amount of property, machinery and equipment

$\mathrm{Ai}, \mathrm{t}$ : Total assets of the company

Tii, $\mathrm{t}=$ Time, the time factor

$(\alpha 5+\alpha 4+\alpha 3+\alpha 2+\alpha 1)=$ specific estimated factors to the company $\mathrm{i}$

To estimate the specific factors of each company, consistent with the study, the formula TA (total accruals for each firm in each financial year) can be set as an estimate of accruals, non-discretionary to form on the left above formula (No. 3):

$\mathrm{TA}=\mathrm{a}_{1}\left(1 / \mathrm{MV}_{\mathrm{i}, \mathrm{t}}\right)+\mathrm{a}_{2}\left(\Delta \mathrm{REV}_{\mathrm{i}, \mathrm{t}}-\Delta \mathrm{REC}_{\mathrm{i}, \mathrm{t}}\right) / \mathrm{MV}_{\mathrm{i}, \mathrm{t}}+\mathrm{a}_{3}\left(\mathrm{PPE}_{\mathrm{i}, \mathrm{t}} / \mathrm{MV}_{\mathrm{i}, \mathrm{t}}\right)+\mathrm{a}_{4}\left(\mathrm{~A}_{\mathrm{i}, \mathrm{t}} / \mathrm{MV}\right)+\varepsilon_{\mathrm{t}}$

Moreover, 71 companies' financial statements, sample is extracted and company's specific factors $(\alpha 5+\alpha 4+$ $\alpha 3+\alpha 2+\alpha 1$ ) was calculated. Thus, the possibility of determining the amount NDA (non-discretionary accruals), was provided for each year - company. With respect to the total non-discretionary accruals and accruals for each year and each company is calculated, discretionary accruals (DA) by using equation (1) is calculated.

Control variables: FIN t: It has been raised since external financing as an important factor that may encourage the manager to the optimistic forecast. FIN is a dummy that takes one variable if the long-term debt or stock been added to at least $20 \%$, and is zero otherwise.

ROA t-1: In order to control the potential effects on the error performance of the company forecast earnings and accruals, return on assets as a control variable is considered the profit before tax divided by total assets, Weisbach (1988) \& Koch (2002).

$\mathrm{Z} \mathrm{t}$-1: In order to control the potential effects of financial crisis on earnings forecast errors and accruals, financial indicators are considered as control variables.

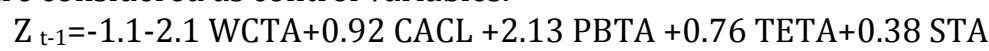

Foreign investments in the financial crisis index proposed by Altman (1968) are used.

WCTA: working capital to total assets ratio.

CACL: ratio of current assets to current liabilities.

PBTA: profit before interest and taxes to total assets ratio.

TETA: the ratio of equity to total assets.

STA: sales to total assets ratio.

Horizont: The number of days that management announced before the actual earnings per share forecast. True to the forecast period to announce date of profit, it will make less ambiguity; the result would be more accurately.

Return $_{i t}$ : Mac Nickels (1989) explains the negative relationship between stock returns and earnings forecast error, which indicates that stock prices reflect information beyond the information contained in management forecasts of earnings. Common stock returns is granted to the holder of shares during a fiscal period.

Cash and receivables from the capital increase - dividends passed + the market value at the beginning of the year - the company's market value at year end

Market value at beginning of year

MFEt-1: The prediction accuracy of the above control variables also partly reflects past management forecast accuracy of earnings management in the future. Therefore, last year's management earnings forecast errors have been considered as well as control variables in the model.

$\mathrm{M} / \mathrm{B}_{\mathrm{t}-1:}$ Company growth is controlled as well, because the evaluation of companies with high growth largely depends on the expected future cash flows (Relative to the value of existing assets), market demand and the public accurately disclose information to intensify prospective. Capital market value divided by book value of capital (equity) financial period. 
Ln Size: Different control variables related to the environment, public information that might balance the bias anticipated earnings affect cost - benefit for profits them, is also considered in the model. Variable size of the companies that control large corporations and companies by a large number follow the analysts are faced with more general and therefore more motivated to avoid large errors in forecasting their earnings. In this study to determine the size, the natural logarithm of market value in the end of fiscal year has been used.

Uncertainty in the estimates of the business-operating environment necessarily creates management control over the following three variables have been proposed to control the operational environment of uncertainty. In this study to determine, the size of the natural logarithm of market value at year-end financial capital has been used.

SALE-GR-VOL t-1 (fluctuating sales growth): standard deviation of sales growth over the past 3 years (including year $\mathrm{t}-1$ ) divided by average sales growth over the same period.

CFO-VOL t-1 (fluctuations in operating cash flows): standard deviation of operating cash flow (total assets divided by beginning of period) during the past 3 years (including year t-1) divided by average operating cash flow (total assets divided by beginning period) during the same period.

OP-CYCLE t-1 (operating cycle), which is calculated thus:

OPCYCLE $=365 /($ S t-1 / AAR t-1) $+365 /($ CGS t-1 / AI t-1)

Where the $\mathrm{S} \mathrm{t}-1$ is (Sales), AAR t-1 (average accounts receivable business), CGS $\mathrm{t}-1$ (cost of goods sold the company) and AI t-1 (average inventory company).

POSt-1: It is a dummy variable, if a number of discretionary accruals are positive; it is one and is zero otherwise.

Negt-1: It is a dummy variable if a number of discretionary accruals are negative; it is one and is zero otherwise.

\section{Statistical methods for testing hypotheses}

Statistical tests: To analyze hypotheses of this study, multiple regression analysis was used. Required statistical tests and the type of statistics used for multivariate regression analysis, $95 \%$ confidence level in the table number 1 is given.

Table 1: Statistical tests for multivariate regression analysis

\begin{tabular}{lll}
\hline Type of used statistic & Type of used test & Hypotheses \\
\hline Kolmogorov - Smirnov test & Normality test & \\
statisticsT and F & Significance tests & All hypotheses \\
TestVIF & Auto correlation test for model coefficients & \\
test Durbin-Watson & Test of auto correlation of model's error & \\
\hline
\end{tabular}

\section{Data Analysis}

One of the main assumptions of regression is normality of pattern residues. To estimate the final model of research, it is used of independent variables, and then the final regression model is estimated. KolmogorovSmirnov test is aforementioned hypothesis is tested. Given the significant level for the years 2007 until 2011 MFEt are $0 / 002,000 / 0,0 / 001,000 / 0$ and $0 / 000$ respectively that all of them are less than $0 / 05$, so the zero hypothesis of test, mean Normality of the data for this variable is not rejected by the normal distribution of variables in different years, but the possibility for the logarithm of this variable, respectively, are $846 / 0$ $889 / 0$ 842/0 715/0 956/0, that all of which are more than 0/05 that shows the logarithmic distribution of this variable is normal. 
Table 2: Test Kolmogorov - Smirnov

\begin{tabular}{|c|c|c|c|c|c|c|c|c|}
\hline \multirow[b]{2}{*}{ significance } & \multirow{2}{*}{$\begin{array}{l}\text { Kolmogorov } \\
\text {-Smirnov } \\
\text { test }\end{array}$} & \multicolumn{3}{|c|}{ differences } & \multicolumn{4}{|c|}{ Parameters (normal) } \\
\hline & & negative & positive & total & $\begin{array}{l}\text { Standard } \\
\text { deviation }\end{array}$ & mean & Nos & year \\
\hline $0 / 002$ & $1 / 881$ & $-0 / 263$ & $0 / 244$ & $0 / 263$ & $0 / 89875$ & $0 / 5692$ & 71 & $\begin{array}{l}2007 \\
\text { MFE }\end{array}$ \\
\hline $0 / 000$ & $2 / 456$ & $-0 / 334$ & $0 / 288$ & $0 / 334$ & $1 / 41572$ & $0 / 6064$ & 71 & 2008 \\
\hline $0 / 001$ & $2 / 004$ & $-0 / 249$ & $0 / 237$ & $0 / 249$ & $1 / 06297$ & $0 / 7217$ & 71 & 2009 \\
\hline $0 / 000$ & $2 / 880$ & $-0 / 337$ & $0 / 342$ & $0 / 342$ & $3 / 46092$ & $1 / 4560$ & 71 & 2010 \\
\hline $0 / 000$ & $2 / 749$ & $-0 / 326$ & $0 / 329$ & $0 / 329$ & $2 / 92548$ & $1 / 3202$ & 71 & 2011 \\
\hline $0 / 846$ & $0 / 613$ & $-0 / 084$ & $0 / 086$ & $0 / 086$ & $1 / 37998$ & $1 / 2426$ & 71 & $\begin{array}{l}2007 \\
\text { LN(MFE) }\end{array}$ \\
\hline $0 / 889$ & $0 / 581$ & $-0 / 062$ & $0 / 081$ & $0 / 081$ & $1 / 75198$ & $1 / 6503$ & 71 & 2008 \\
\hline $0 / 842$ & $0 / 616$ & $-0 / 077$ & $0 / 045$ & $0 / 077$ & $1 / 20389$ & $-0 / 9635$ & 71 & 2009 \\
\hline $0 / 715$ & $0 / 698$ & $-0 / 061$ & $0 / 085$ & $0 / 085$ & $1 / 48776$ & $-0 / 8346$ & 71 & 2010 \\
\hline $0 / 956$ & $0 / 512$ & $-0 / 062$ & $0 / 063$ & $0 / 063$ & $1 / 59901$ & $-0 / 8679$ & 71 & 2011 \\
\hline
\end{tabular}

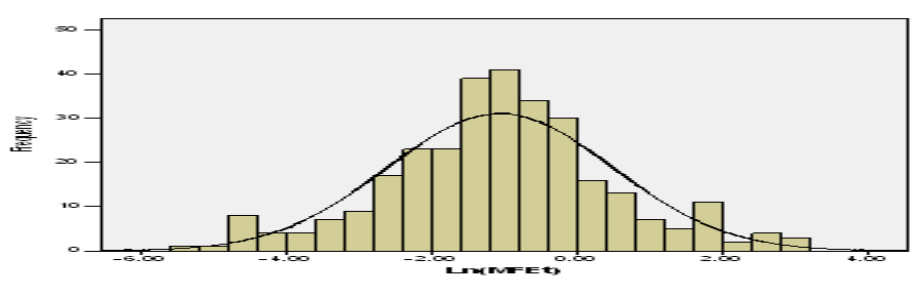

Auto correlation of residuals using the Durbin-Watson: If the test statistic is in the range $5 / 1$ to $5 / 2$, Hotest (lack of correlation between errors) is accepted, otherwise Ho is rejected (there is a correlation between the errors). Durbin - Watson statistic value in models 1,2 and 3, 4 and 5 are $03 / 2,770 / 1,775 / 1$ respectively. These values indicate lack of correlation remaining that shows another regression assumptions.

Descriptive Statistics: In order to analyze data descriptive and inferential analysis research has been used. So, first descriptive character data including maximum, minimum, mean, median, quartile deviation are presented. Descriptive statistics of variables are shown in table 3:

Table 3: Descriptive statistics for explanatory variables in the earnings forecast error

\begin{tabular}{llllll}
\hline minimum & Maximum & $\begin{array}{l}\text { Quartile } \\
\text { deviation }\end{array}$ & median & mean & variables \\
\hline$-5 / 32$ & $3 / 04$ & $0 / 403$ & $-1 / 0881$ & $-1 / 079$ & Earnings forecast error \\
$-0 / 53$ & $1 / 07$ & $0 / 769$ & $0 / 0101$ & $0 / 0143$ & Discretionary accruals \\
$-0 / 32$ & $0 / 7$ & $2 / 868$ & $0 / 1029$ & $0 / 1187$ & Assets returns \\
$-2 / 32$ & $3 / 49$ & $2 / 968$ & $0 / 6574$ & $0 / 6612$ & Financial disaster index \\
$-69 / 6$ & $341 / 83$ & $5 / 073$ & $10 / 29$ & $24 / 98$ & Stock returns \\
$-7 / 46$ & $3 / 02$ & $1 / 443$ & $-1 / 1378$ & $-1 / 186$ & Last year earnings forecast error \\
311 & 541 & $-0 / 249$ & 471 & $461 / 29$ & Time between forecast and announcement \\
$0 / 5$ & $28 / 42$ & $7 / 349$ & $2 / 514$ & $4 / 1439$ & Company's growth \\
$8 / 93$ & $15 / 73$ & $-0 / 524$ & $12 / 2124$ & $12 / 29$ & Size of company \\
$-32 / 61$ & $154 / 13$ & $13 / 129$ & $1 / 2681$ & $0 / 991$ & Operational cash flow fluctuation \\
$-17 / 65$ & $37 / 45$ & $20 / 513$ & $0 / 8426$ & $1 / 3102$ & Sales growth fluctuation \\
12 & 810 & $50 / 223$ & $238 / 12$ & $255 / 132$ & Operational cycle \\
\hline
\end{tabular}


The results of the first hypothesis: Results of the test the first hypothesis suggests a negative relationship (coefficient 1/539- for DAt-1) between discretionary accruals and earnings forecast error, that this negative relationship is significant at $\div 95$ confidence. Coefficient of determination (r square) of $26 \%$ indicates that the explanatory variables (independent and control), explain 26\% change in earnings forecast error. In addition, since the F-statistic at level of $0 / 000$ is significant, the model has the necessary competence. Safely stated that there is a significant negative relationship the level of accruals from the previous year and the company earnings forecast this year. In other words, more the level of discretionary accruals for previous year, earnings forecast error would be less in this year. The first research hypothesis is accepted at the level of 5\% error. These findings with the findings of his research in Weihong Xu (2009) and Kasznik (1999). The results of the first research hypothesis are presented in table 4.

Table 4: Results of the test the first hypothesis

\begin{tabular}{|c|c|c|c|c|c|}
\hline \multicolumn{2}{|c|}{ statistics } & \multirow{2}{*}{ significance } & \multirow{2}{*}{ T-statistics } & \multirow{2}{*}{$\begin{array}{l}\text { Coefficients' } \\
\text { variables }\end{array}$} & \multirow{2}{*}{$\begin{array}{l}\text { variables } \\
\text { VIF }\end{array}$} \\
\hline VIF & tolerance & & & & \\
\hline- & - & $0 / 552$ & $-0 / 596$ & $-0 / 858$ & $\mathrm{a}$ \\
\hline $1 / 473$ & $0 / 679$ & $0 / 036$ & $-2 / 112$ & $-1 / 539$ & DA \\
\hline $1 / 073$ & $0 / 932$ & $0 / 680$ & $-0 / 413$ & $-0 / 111$ & FIN \\
\hline $3 / 487$ & $0 / 287$ & $0 / 609$ & $-0 / 512$ & $-0 / 689$ & ROA \\
\hline $1 / 862$ & $0 / 537$ & $0 / 028$ & $-2 / 208$ & $-0 / 470$ & $\mathrm{Z}$ \\
\hline $1 / 033$ & $0 / 968$ & $0 / 224$ & $1 / 219$ & $0 / 003$ & Horizon \\
\hline $1 / 061$ & $0 / 942$ & $0 / 566$ & $0 / 575$ & $0 / 001$ & Return \\
\hline $1 / 805$ & $0 / 554$ & $0 / 007$ & $2 / 739$ & $0 / 249$ & LN MFE \\
\hline $1 / 484$ & $0 / 674$ & $0 / 137$ & $1 / 494$ & $0 / 051$ & $\mathrm{M} / \mathrm{B}$ \\
\hline $1 / 358$ & $0 / 736$ & $0 / 298$ & $-1 / 044$ & $-0 / 085$ & LN Size \\
\hline $1 / 093$ & $0 / 915$ & $0 / 820$ & $-0 / 228$ & $-0 / 004$ & SA-GR-VOL \\
\hline $1 / 067$ & $0 / 937$ & $0 / 809$ & $-0 / 242$ & $-0 / 004$ & CFO-GR-VOL \\
\hline $1 / 117$ & $0 / 895$ & $0 / 038$ & $-2 / 085$ & $-0 / 002$ & CYCLE \\
\hline $0 / 512$ & \multicolumn{2}{|c|}{ Adjusted r square } & $5 / 333$ & F statistics & \\
\hline $0 / 262$ & \multicolumn{2}{|c|}{ Correlation coefficient (R) } & $0 / 000$ & significance & \\
\hline
\end{tabular}

Results from the second and third hypotheses: Hypothesis 2 and 3 and in cross-impact analysis is based on total discretionary accruals. In the first step, discretionary accruals coefficient (021/3- ) has a significant negative relationship with MFE (consistent with the results of the first hypothesis, respectively). However, by considering the positive accruals besides debt (DFIN), means the variable DAt- ${ }^{*}$ POS * DFIN by the coefficient factor (869/6), has motion negative relationship to the table and the positive and negative relationships are ultimately positive. Since in the previous year $(\mathrm{t}-1)$ through debt financing expected in the current year $(\mathrm{t})$ Therefore, with increasing discretionary accruals in the previous year $(\mathrm{t}-1)$ is trying to increase profits last year. So during this year, do financing through debt, which makes a profit on the profit the previous year $(t-1)$ bold report, earnings forecast of this year will also be reported with a high degree of optimism. Reason for this is that if the current year earnings forecast $(\mathrm{t})$ is less than the earnings reported in the previous year ( $\mathrm{t}-1$ ) is because bad news in the market is signaling (the signaling theory) that share prices drop and returns will be negative. In addition, cause hypothesis 2 is admitted in $5 \%$ significance. Companies that manage accounting earnings forecast error are more conservative for less politic expense. Therefore, the third hypothesis is rejected at the 5\% error. With the separation of positive and negative accruals, the results can vary due to industry characteristics and unique features as companies. The result is recommended in future studies, researchers can examine in increasing the number of negative accruals on positive accruals with relatively equal weights, and other accruals, negative edge weights on positive accruals. Now with reference to examples, the latter phase has been confirmed. Results from the second and third hypotheses are presented in table 5. 
Table 5: Results of the second and third hypothesis test

\begin{tabular}{|c|c|c|c|c|c|}
\hline \multicolumn{2}{|c|}{ statistics } & \multirow{2}{*}{ significance } & \multirow{2}{*}{ T-statistics } & \multirow{2}{*}{$\begin{array}{l}\text { Coefficients' } \\
\text { of variables }\end{array}$} & \multirow{2}{*}{$\begin{array}{l}\text { variables } \\
\text { VIF }\end{array}$} \\
\hline VIF & tolerance & & & & \\
\hline- & - & $0 / 736$ & $-0 / 337$ & $-0 / 393$ & A \\
\hline $6 / 806$ & $0 / 147$ & $0 / 042$ & $-2 / 040$ & $-3 / 021$ & DA \\
\hline $1 / 766$ & $0 / 566$ & $0 / 024$ & $-2 / 276$ & $-0 / 496$ & FIN \\
\hline $1 / 977$ & $0 / 506$ & $0 / 000$ & $3 / 983$ & $6 / 869$ & $\mathrm{DA} \times \mathrm{Pos} \times \mathrm{SFIN}$ \\
\hline $2 / 352$ & $0 / 425$ & $0 / 107$ & $-1 / 619$ & $-3 / 139$ & $\mathrm{DA} \times \mathrm{Neg} \times \mathrm{SFIN}$ \\
\hline $3 / 222$ & $0 / 310$ & $0 / 641$ & $-0 / 467$ & $-0 / 789$ & $\mathrm{DA} \times \mathrm{Neg}$ \\
\hline $3 / 614$ & $0 / 277$ & $0 / 931$ & $0 / 086$ & $0 / 165$ & DA $\times$ Pos \\
\hline $1 / 022$ & $0 / 978$ & $0 / 587$ & $0 / 544$ & $0 / 001$ & Horizon \\
\hline $1 / 057$ & $0 / 946$ & $0 / 243$ & $1 / 170$ & $0 / 002$ & Return \\
\hline $1 / 250$ & $0 / 800$ & $0 / 730$ & $0 / 346$ & $0 / 009$ & $\mathrm{M} / \mathrm{B}$ \\
\hline $1 / 231$ & $0 / 812$ & $0 / 068$ & $-1 / 833$ & $-0 / 115$ & LN Size \\
\hline $0 / 239$ & \multicolumn{2}{|c|}{ Adjusted r square } & $7 / 621$ & F statistics & \\
\hline $0 / 489$ & \multicolumn{2}{|c|}{ Correlation coefficient (R) } & $0 / 000$ & Significance & \\
\hline
\end{tabular}

Results of the fourth and fifth hypotheses: In hypotheses 4 and 5 as well as hypotheses 2 and 3 of the total cross-impact analysis and total discretionary accruals are based for analyzing. Discretionary accruals coefficient (021/3-) has a significant negative relationship with MFE (in accordance with the results of the first hypothesis). There are currently considering the next release of positive accruals stocks (SFIN) DAt- ${ }^{*}$ POS * SFIN with a variable ratio (869/6), the relationship move in diverse direction and cause negative relationship move to be more positive and cause relationship be the positive end. The fourth research hypothesis is accepted at the $5 \%$ error. From another angle with respect to the existence of negative equity accruals (SFIN) the variable DAt- 1 * NEG * SFIN said in relation to the first hypothesis, the negative (stronger) relation is found. This relation implies that the company getting on the brink of financial liabilities states less earnings forecast error. This means that more negative accruals causeless earnings forecast error. In other words, the company earnings forecast will follow a conservative approach in reducing the political cost. In other words, companies that manage accounting more conservatively make less earnings forecast error. Results from the fourth and fifth research hypotheses are presented in table 6.

Table 6: Results of testing hypothesis of fourth and fifth

\begin{tabular}{|c|c|c|c|c|c|}
\hline $\begin{array}{l}\text { statistics } \\
\text { VIF }\end{array}$ & tolerance & significance & $\begin{array}{l}\text { T- } \\
\text { statistics }\end{array}$ & $\begin{array}{l}\text { Coefficients' } \\
\text { of variables }\end{array}$ & Variables \\
\hline- & - & $0 / 719$ & $0 / 36$ & $0 / 402$ & A \\
\hline $9 / 611$ & $0 / 104$ & $0 / 000$ & $-3 / 928$ & $-6 / 075$ & DA \\
\hline $1 / 849$ & $0 / 541$ & $0 / 018$ & $-2 / 377$ & $-0 / 673$ & FIN \\
\hline $1 / 585$ & $0 / 631$ & $0 / 045$ & $1 / 976$ & $4 / 614$ & $\mathrm{DA} \times \mathrm{Pos} \times$ SFIN \\
\hline $1 / 300$ & $0 / 769$ & $0 / 002$ & $-3 / 114$ & $-11 / 958$ & $\mathrm{DA} \times \mathrm{Neg} \times \mathrm{SFIN}$ \\
\hline $4 / 086$ & $0 / 245$ & $0 / 145$ & $1 / 462$ & $3 / 109$ & $\mathrm{DA} \times \mathrm{Neg}$ \\
\hline $5 / 188$ & $0 / 193$ & $0 / 002$ & $3 / 163$ & $6 / 642$ & $\mathrm{DA} \times \mathrm{Pos}$ \\
\hline $1 / 026$ & $0 / 974$ & $0 / 680$ & $0 / 414$ & $0 / 001$ & Horizon \\
\hline $1 / 044$ & $0 / 958$ & $0 / 464$ & $0 / 734$ & $0 / 001$ & Return \\
\hline $1 / 231$ & $0 / 812$ & $0 / 953$ & $-0 / 059$ & $-0 / 001$ & $\mathrm{M} / \mathrm{B}$ \\
\hline $1 / 242$ & $0 / 805$ & $0 / 005$ & $-2 / 838$ & $-0 / 173$ & LN Size \\
\hline $0 / 233$ & \multicolumn{2}{|c|}{ Adjusted r square } & $8 / 014$ & F statistics & \\
\hline $0 / 483$ & \multicolumn{2}{|c|}{ Correlation coefficient (R) } & $0 / 000$ & significance & \\
\hline
\end{tabular}




\section{Conclusion}

Importance of anticipated profits is to the extent that it affiliated with the real value. Less the extent of this deviation more accurate prediction (Siavaramakrishnan, 2007).The earnings per share go beyond expectations, the market is optimistic about its vision and it will be good news (Payne, 2008).With the results of first hypothesis, it was confirmed that corporate executives in order to reduce the prediction error, increase accruals accordance with agency theory. In 2, 3, 4 and 5 hypotheses with separation of positive and negative accruals and existence of financing (through debt and equity), different results were obtained from the first hypothesis. Results confirm hypotheses 2 and 4 indicate that the management of this landscape through debt or equity financing to make a bold prediction on the benefits brought to realize their goals.

\section{Practical suggestions:}

- Reduce the prediction error can be caused by factors such as management's opportunistic behavior, to prevent stock prices, encouraging investors to buy shares and raise capital, obtain financing facility, commission and agency costs, avoidance of legal claims from shareholders, to prevent degradation and maintain credibility of company managers (job security) through controlling accruals. It is recommended to investors and analysts during the analysis of accounting information, quality and sustainability of accruals should be considered in their decisions.

- It is recommended to the standard setters and legislators, to note that the formulation of standards to strengthen and forced to disclose information does not necessarily mean improved environmental management information. It can be used as a tool in the management interests.

- It is recommended to investors in Tehran Stock Exchange focused on authorized management to choose the allowable alternative accounting procedures, the management actions identified in the estimates and accruals, and the amount of optimism and pessimism in management forecasts of future profits in terms of adjusting their own decisions.

- It is recommended to investors, analysts and other stakeholders that besides using the forecasting methods, also consider to the factors listed in table 1.

Limitations of the study: The following are main limitations in most research. It is hoped that in future remedial changes and efforts to help researchers overcome these problems:

1) The overall level of industries (19 industries - classified according to the Tehran Stock Exchange) was implemented in each industry may lead to different results for each industry.

2) There are many variables that may have affected a negative relationship between earnings forecast errors and accruals. Some of these variables in the study according to previous research are controlled. However, the coefficient $r$-square of the models shows that in addition to the above variables, there are other variables that may affect these relationships.

Suggestions for future research: The proposed following research topics can be considered as topics for future study:

- Comparative study based on the audited and no audited predictions earnings.

- Study the separation of positive and negative accruals and earnings forecast error.

- Conduct research to examine the relationship between earnings prediction error and accruals in different industries.

- Evaluate the usefulness of mandatory disclosure of profit forecasts by Tehran Stock Exchange.

- Examine the relationship between management earnings forecast error with the accruals anomaly.

- The effect of micro and macro indicators on earnings forecast error.

\section{References}

Brockman, P. \& Cicon, J. (2008). The Information Content of Management Earnings Forecasts: An Analysis of Hard versus Soft Data, under review at Journal of Accounting Research.

Dunstan, K., Gallery, G. \& Truong, T. P. (2009). The impact of disclosure reform and alternative sources of earnings-related information on the market reaction to firm-based earnings-related disclosures, working paper, School of Accounting and Commercial Law, Victoria University of Wellington. 
Dunstan, K., Gallery, G. \& Truong, T. P. (2011). Public regulatory reform and management earnings forecasts in a low private litigation environment. Accounting and Finance, 51(2), 437-465.

Fang, W. V . (2009). The Role of Management Forecasts Precision in Predicting Management Forecasts Error, "Rutgers University ,http://www.ssrn.com.

Frijns, B., Gilbert, A. \& Tourani-Rad, A. (2008). Insider trading, regulation, and the components of the bid-ask spread. The Journal of Financial Research, 31(3), 225-246.

Gong, G., Yue Li, L. \& Xie, H. (2009). The Association between Management Earning Forecast Errors and Accruals. The Accounting Review, 84(2), 497-530

Hirst, E., Koonce, L. \& Venkatarman , S. (2008). Management Earnings Forecasts: A Review and Frameworks. Accounting Horizon, 22(3), 315-338.

Huang, M., Marsden, A. \& Poskitt, R. (2009). The impact of disclosure reform on the NZX's financial information environment. Pacific-Basin Finance Journal, 17, 460-478.

Hutton, P., Amy, P. \& Stocken, C. (2009). Prior Forecasting Accuracy and Investor Reaction to Management Earnings Forecasts, http://www.ssrn.com.

Hendriksen, E. S. \& van Breda, M. F. (1992). Accounting Theory, 5th ed. Burr Ridge: Irwin

Kasznik, R. (1999). On the Association between Voluntary Disclosure and Earnings Management. Journal of Accounting Research, 37, 57-81.

Jog, V. \& McConomy, B. (2003). Voluntary Disclosure of Management Earnings Forecasts in IPO Prospectuses. Journal of Business, Finance \& Accounting, 30(1,2), 125-167. 91.

Koch, A. (2002). Financial Distress and the Credibility of Management Earnings Forecasts, Working paper, Carnegie Mellon University Pittsburgh, PA.

McNichols, M. (1989). Evidence of informational asymmetries from management earnings forecasts and stock returns. The Accounting Review, 64 (1), 1- 27.

Pae, J., Thornton, D. (2010). The association Between Accounting Conservatism and Analysts' Forecast Inefficiency. Working Paper, Korea University Business School and Queen's University.

Payne, J. L. (2008). The Influence of Audit Firm Specialization on Analysts' Forecast Errors. Auditing A Journal of Practice \&Theory, 27(2), 109-136.

Rogers, J. \& Stocken, P. C. (2005). Credibility of management forecast. The Accounting Review, 80(4), 12331260.

Rees, L. \& Siavaramakrishnan, K. (2007). The Effect of Meeting or Beating Revenue Forecasts on the Association between Quarterly Returns and Earnings Forecast Errors. Contemporary Accounting Research, 24(1), 259-90.

Weihong, X. (2009). Do management earnings forecasts incorporate information in accruals? Journal of Accounting and Economics, 49, 227-24

Weisbach, M. S. (1988). Outside directors and CEO turnover. Journal of Financial Economics , 20, 431-460. 